\title{
Introduction: Music, from Intangible Cultural Heritage to the Music Industry
}

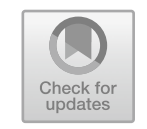

\author{
Blanca de-Miguel-Molina $(\mathbb{D})$ and Rafael Boix-Doménech $(\mathbb{D}$
}

Our first contact with music is almost certainly in our childhood when our parents sing lullabies to us at bedtime. In a community where music is important, these songs are likely to be successfully transmitted from one generation to the next. This is similar to the concept of intangible cultural heritage and how it is transmitted. Intangible cultural heritage, according to the UNESCO's 2003 Convention (2018a), refers to "the oral traditions and expressions, performing arts, social practices, rituals and festive events" that are transmitted from generation to generation. The UNESCO List of Intangible Cultural Heritage has been extended with new inscriptions since 2008. The terms music and song are present in 304 of the 584 elements on the list $(52 \%)$, referring to music alone or combined with other dimensions such as dance and poetry. Table 1 shows some famous examples that feature on the list, such as the Tango in Argentina and Uruguay, Spanish flamenco, the fado from Portugal and Jamaican reggae music (2018).

Why have these elements been considered expressions of intangible cultural heritage and added to the list by the UNESCO? The answer is related to artistic expressions which are important factors of identity for communities in specific territories. For example, the Tango nomination stated that it is part of the cultural identity of inhabitants in the La Plata region, while flamenco is synonymous with identity in the Spanish regions of Andalusia, Murcia and Extremadura. Although convention points out that communities are more open than territories, as generations move to other countries or to cities, intangible heritage must be present in the territory. Communities in the cases cited recognise these expressions as heritage and work

\footnotetext{
B. de-Miguel-Molina ( $₫)$

Department of Business Organisation, Universitat Politècnica de València, Valencia, Spain e-mail: bdemigu@omp.upv.es

R. Boix-Doménech

Departament d'Estructura Econòmica, Universitat de València, Valencia, Spain

e-mail: rafael.boix@uv.es
} 
Table 1 Examples of musical heritage on the UNESCO list

\begin{tabular}{|c|c|c|c|c|c|}
\hline $\begin{array}{l}\text { Intangible } \\
\text { cultural } \\
\text { heritage }\end{array}$ & Year in the list & Country & Territory & Concept & SDG \\
\hline $\begin{array}{l}\text { Music and } \\
\text { dance of } \\
\text { Dominican } \\
\text { Bachata }\end{array}$ & 2019 & $\begin{array}{l}\text { Dominican } \\
\text { Republic }\end{array}$ & & $\begin{array}{l}\text { Music, dance, } \\
\text { social gathering }\end{array}$ & \\
\hline $\begin{array}{l}\text { Reggae } \\
\text { music }\end{array}$ & 2018 & Jamaica & & Music & 10 \\
\hline $\begin{array}{l}\text { Music and } \\
\text { dance of the } \\
\text { merengue }\end{array}$ & 2016 & $\begin{array}{l}\text { Dominican } \\
\text { Republic }\end{array}$ & & Music and dance & 10 \\
\hline $\begin{array}{l}\text { Traditional } \\
\text { Vallenato } \\
\text { music* }\end{array}$ & 2015 & Colombia & $\begin{array}{l}\text { Greater } \\
\text { Magdalena } \\
\text { region }\end{array}$ & Music & \\
\hline Fado & 2011 & Portugal & Lisbon & Music and poetry & \\
\hline Mariachi & 2011 & Mexico & & $\begin{array}{l}\text { Music and } \\
\text { orchestras }\end{array}$ & \\
\hline Flamenco & 2010 & Spain & $\begin{array}{l}\text { Andalusia, } \\
\text { Murcia, } \\
\text { Extremadura }\end{array}$ & $\begin{array}{l}\text { Music, dance, } \\
\text { instruments }\end{array}$ & \\
\hline Tango & 2009 & $\begin{array}{l}\text { Argentina and } \\
\text { Uruguay }\end{array}$ & $\begin{array}{l}\text { Buenos Aires } \\
\text { and } \\
\text { Montevideo }\end{array}$ & Music and dance & 16 \\
\hline
\end{tabular}

* On the List in Need of Urgent Safeguarding

Source https://ich.unesco.org/en/lists

together with national and local authorities to ensure this intangible heritage is safeguarded and transmitted from one generation to the next through education and festivals (UNESCO, 2009, 2010, 2011a, 2018b). Therefore, communities create, maintain and transmit intangible heritage (UNESCO, 2011b). The UNESCO also verifies that the community's participation in the nomination process is carried out following the Free, Prior and Informed Consent (FPIC) approach. This is a tool that the United Nations requires in projects to ensure the participation of involved communities (FAO, 2016).

The UNESCO indicates the importance of safeguarding. From a cultural perspective, carrying out an inventory of cultural heritage and making it available to people contributes to the safeguarding process. Digitalisation has enabled the inventory of sound archives that can be conserved and transmitted to future generations (Gonzaga Videira \& Martins Rosa, 2017). The existence of museums related to the musical expressions listed as intangible heritage is an important factor in collecting and preserving traditions in audiovisual archives (Stoffel \& Victor, 2017). The four examples of intangible heritage cited have museums associated with their musical styles which ensure their transmission to the community, younger generations and tourists. 
The preservation of musical heritage requires the transmission of expressions from one generation to the next. From a business point of view, record labels and other firms in the music industry value chain can support music heritage inventory and safeguarding. In some of the examples cited, the nomination indicates that the cultural expressions included in the list have influenced other musical styles. This is especially true when singers and bands become famous and make a style known across the world. It is more likely that their music will be recorded and safeguarded for future generations. For example, the catalogue of Universal Music Group includes recordings by Bob Marley. However, labels are businesses, and they need to ensure the sustainability of their own firms. Cooperation with the UNESCO might help to increase the number of styles available in their catalogues, especially those in need of safeguarding.

Transmission of music genres, as in the cases of fado and reggae, increases because people listen to music and select these styles, because recorded labels include these styles in their catalogues and they are then distributed through streaming platforms, and because experiences are designed with a focus on music, with local culture being integrated into these experiences. These experiences include festivals, live music performances and experiences designed by local guests for tourists.

The music industry covers more than intangible cultural heritage. The number of people who listen to music everyday indicates the importance of music in our lives. If the percentage of people listening to music is high, the styles of music they can discover every day will increase (Fitterman Radbill, 2017). In Spain, 70.6\% of people and $90 \%$ of students listen to music every day. ${ }^{1}$ Moreover, the devices most used for listening to music are the radio $(65.7 \%)$ and mobile phones $(48.5 \%)$, while $53.2 \%$ connect directly to the Internet. Data indicate that $22.3 \%$ of people in Spain listen to recorded flamenco music and $10.7 \%$ listen to reggae music. In Colombia, the most popular music genre in recorded music in 2017 was Vallenato. ${ }^{2}$ This genre has been on the UNESCO List as Cultural Heritage in Need of Urgent Safeguarding since 2015. In Argentina, the Tango is not among the most listened to genres, ranking tenth in importance and listened to by $34.5 \%$ of the population, ${ }^{3}$ while rock is listened to by $68 \%$ and reggaeton by $54.2 \%$. All these data indicate the influence of music in other territories.

Music is distributed through music streaming platforms, radio, television and also via podcasts. In 2019, $21.4 \%$ of people in Spain had a subscription to a music streaming platform, $10 \%$ of whom had a premium subscription. Around $20 \%$ of people with a subscription listened to flamenco and $16 \%$ to reggae music through their streaming service. IFPI (2019) estimated that $89 \%$ of people across the world listen to music through streaming platforms. However, this percentage is lower when age is considered and drops to 54\% for people between 35 and 64 years old. The number of platforms available on the market has increased in recent years, offering the different styles available to a wider audience. They feature those cited in Table 1 in

\footnotetext{
${ }^{1}$ Ministry of Culture, Spain. Survey about cultural participation in 2018-2019.

${ }^{2}$ DANE, Colombia. 2017 (available at Statista).

${ }^{3}$ Ministerio de Cultura de Argentina (available at Statista).
} 
the UNESCO List. However, these have been included because there are well-known artists who are references to specific styles of music.

Nowadays, experiences are an important element in the value proposition of tourism companies and music is at the centre of some of these experiences. Examples can be observed in Airbnb, hotel chains, music record labels, tourism destinations and music festivals.

In the hospitality sector, experiences have been identified with the customer journey and the focus is combined with the hotel experience. These experiences involve the design of the hotel, facilities, front-line employees and other customers (Kandampully et al., 2018). However, in the sharing economy, studies have concluded that authenticity in the experience is perceived as a differentiation factor in accommodation services (Mody et al., 2019). Customers conceive authenticity as access to the local community that is people and culture (Li et al., 2019). Authenticity is a dimension of the Airbnb experiences identified in these studies. Mody et al. (2019) found that customers perceive better immersion experiences in the local community through Airbnb than through hotels.

Airbnb experiences are closely connected to the idiosyncrasy of countries. Experiences can be also found in Tripadvisor, although this website does not refer to them as experiences but as things to do or tours. The two websites offer music experiences centring on the Tango in Argentina, the fado in Portugal, reggae in Jamaica and flamenco in Spain. Customers can become immersed in local communities and live authentic and unique experiences ( $\mathrm{Li}$ et al., 2019).

Music is at the centre of the value proposition in some hotel chains, which try to differentiate themselves from their competitors by creating a unique atmosphere. For example, the Hard Rock Hotel experience is based on rock music and Disney Hotels \& Resorts offer Mariachi performances. The Universal Music Group record label is planning on opening some hotels with their own music venue in the United States, for experiences that might consist of a combination of hotels and festivals. All these are examples of the ability of resorts to disseminate current and past music, including the styles listed as intangible heritage by the UNESCO.

Some tourist destinations are associated with music, as is the case of Ibiza, in the Balearic Islands. Berrozpe et al. (2017) analysed the brand image of the island and found that the cultural dimensions perceived by people were related to electronic music. Music is present in the airport, hotels, beaches and discotheques. If we think about Jamaica as a destination, we probably think about Bob Marley and reggae music. When non-Spanish people think about Spain, they usually think about flamenco.

Festivals and live music concerts are one of the main offerings that destinations use to attract tourists as a means to transmit their intangible heritage. Festivals aimed at preserving and transmitting local heritage engage people from a community as well as involving audiences from other municipalities and countries who appreciate the significance of that heritage. For example, 600,000 participants attended the Buenos Aires Tango Festival in 2017. ${ }^{4}$ Live music concerts have become an important activity

${ }^{4}$ Statista. 
to transmit musical heritage. In Spain, live flamenco concerts were the second most popular type of concert in terms of attendance in 2019. ${ }^{5}$ In Portugal, around 417,000 concertgoers went to live fado music concerts. This was equivalent to $2.4 \%$ of total live performance participants. ${ }^{6}$

All the examples presented in this introduction and those that are included in this book indicate how important music is for people across the world and how it engages them, offering many styles and degrees of involvement that can be adapted to everyone. This introduction has shown that music as intangible heritage and music as a business can go hand in hand, extending the opportunity for the former to become well known and making people more aware of the need to safeguard it.

\section{References}

Berrozpe, A., Campo, S., \& Yagüe, M. J. (2017). Understanding the identity of Ibiza, Spain. Journal of Travel \& Tourism Marketing, 34(8), 1033-1046.

FAO. (2016). Free, prior and informed consent. Manual for project practitioners. FAO, Rome. http://www.fao.org/3/I6190E/i6190e.pdf.

Fitterman Radbill, C. (2017) Introduction to music industry: An entrepreneurial approach (2nd ed.). Routledge.

Gonzaga Videira, T., \& Martins Rosa, J. (2017). A new online archive of encoded fado transcriptions. Empirical Musicology Review, 12(3/4), 229-243.

IFPI. (2019). Music listening 2019: A look at how recorded music is enjoyed around the world. https://www.ifpi.org/resources/.

Instituto Nacional de Estatística. (2020). Estatísticas da Cultura 2019. INE, Lisbon. www.ine.pt/ xurl/pub/71882171.

Kandampully, J., Zhang, T. C., \& Jaakkola, E. (2018). Customer experience management in hospitality: A literature synthesis, new understanding and research agenda. International Journal of Contemporary Hospitality Management, 30(1), 21-56.

Li, J., Hudson, S., \& So, K. K. F. (2019). Exploring the customer experience with Airbnb. International Journal of Culture, Tourism and Hospitality Research, 13(4), 410-429.

Mody, M., Hanks, L., \& Dogru, T. (2019). Parallel pathways to brand loyalty: Mapping the consequences of authentic consumption experiences for hotels and Airbnb. Tourism Management, 74, $65-80$.

Stoffel, A. M., \& Victor, I. (2017). Museums and intangible cultural heritage in Lusophone countries. In M. Stefano \& P. Davis (Eds.), The Routledge companion to intangible cultural heritage (pp. 426-440). Routledge.

UNESCO. (2009). Evaluation of the nominations for inscription on the representative list of the intangible cultural heritage of humanity. ITH/09/4.COM/CONF.209/13 Rev.2. UNESCO, Paris. https://ich.unesco.org/doc/src/ITH-09-4.COM-CONF.209-13-Rev.2-EN.pdf.

UNESCO. (2010). Evaluation of the nominations for inscription on the representative list of the intangible cultural heritage of humanity. ITH/10/5.COM/CONF.202/6. UNESCO, Paris. https:// ich.unesco.org/doc/src/ITH-10-5.COM-CONF.202-6-EN.pdf.

UNESCO. (2011a). Evaluation of the nominations for inscription on the representative list of the intangible cultural heritage of humanity. ITH/11/6.COM/CONF.206/13 Add. UNESCO, Paris. https://ich.unesco.org/doc/src/ITH-11-6.COM-CONF.206-13+Corr.+Add.-EN.pdf.

\footnotetext{
${ }^{5}$ Data from Sgae 2019 (available at Statista).

${ }^{6}$ Instituto Nacional de Estadística (2020).
} 
UNESCO. (2011b). What is intangible cultural heritage? UNESCO, Paris. https://ich.unesco.org/ en/what-is-intangible-heritage-00003.

UNESCO. (2018a). Basic texts of the 2003 convention for the safeguarding of the intangible cultural heritage, 2018 edition. UNESCO, Paris. https://ich.unesco.org/doc/src/2003_Convention_Basic_ Texts-_2018_version-EN.pdf.

UNESCO. (2018b). Evaluation of the nominations for inscription on the representative list of the intangible cultural heritage of humanity. ITH/18/13.COM/10.b+Add.2. UNESCO, Paris. https:// ich.unesco.org/en/decisions/13.COM/10.B.18.

Open Access This chapter is licensed under the terms of the Creative Commons Attribution 4.0 International License (http://creativecommons.org/licenses/by/4.0/), which permits use, sharing, adaptation, distribution and reproduction in any medium or format, as long as you give appropriate credit to the original author(s) and the source, provide a link to the Creative Commons license and indicate if changes were made.

The images or other third party material in this chapter are included in the chapter's Creative Commons license, unless indicated otherwise in a credit line to the material. If material is not included in the chapter's Creative Commons license and your intended use is not permitted by statutory regulation or exceeds the permitted use, you will need to obtain permission directly from the copyright holder.

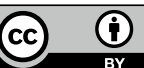

